\title{
A COVID-19-járvány alatti betegelégedettség egy sürgősségi betegellátó osztályon
}

\author{
Deák András ${ }^{1}$ - Fusz Katalin dr. ${ }^{2}$ - Kanizsai Péter dr. ${ }^{1}$ \\ ${ }^{1}$ Pécsi Tudományegyetem, Klinikai Központ, Sürgősségi Orvostani Tanszék, Sürgősségi Betegellátó Osztály, Pécs \\ ${ }^{2}$ Pécsi Tudományegyetem, Általános Orvostudományi Kar, Élettani Intézet, Pécs
}

Bevezetés és célkitüzés: A nagy betegszám a sürgősségi osztályokon a dolgozók megterhelését növeli, a betegelégedettséget csökkenti. Ennek a tendenciának megállítására és javítására több módszert is bevezettünk 2019-ben. A COVID-19-járvány során a betegek a sürgősségi osztályt keresték fel azon panaszaikkal, amelyekkel amúgy a háziorvost vagy a szakambulanciákat keresték volna fel, továbbá a szakdolgozók több mint 15\%-a a Koronavírus Ellátó Központban dolgozott 2020. áprilisban és májusban. Célunk volt felmérni a 2019-ben bevezetett intézkedéseknek, valamint a COVID-19-járvány okozta pluszmegterhelésnek a betegelégedettségre gyakorolt hatásait.

Módszer: Longitudinális, kvantitatív, leíró jellegű, kérdőíves felmérést és dokumentumelemzést végeztünk a Pécsi Tudományegyetem Klinikai Központ (PTE KK) Sürgősségi Orvostani Tanszékének Sürgősségi Betegellátó Osztályán 2019. április 1. és 2020. május 31. között $(n=999)$. A felmérés első részében 354, a második részében 645 kérdőívet elemeztünk, valamint a dokumentumelemzés során a betegszámokat használtuk fel. Az adatelemzéshez leíró statisztikát, kétmintás t-próbát és Mann-Whitney-tesztet végeztünk $(\mathrm{p}<0,05)$.

Eredmények: A felmérés első hónapjában a páciensek és hozzátartozók 51\%-a értékelte pozitívan a PTE KK Sürgősségi Orvostani Tanszékének Sürgősségi Betegellátó Osztályát, míg novemberre ez az arány 99\%-ra emelkedett. A kommunikációs tréninget és egyéb intézkedéseket követően pozitív irányba változott az ápolókról $(Z=-2,25$, $\mathrm{p}=0,024)$, az orvosokról $(\mathrm{Z}=-2,25, \mathrm{p}=0,024)$ és az osztályról $(\mathrm{Z}=-2,24, \mathrm{p}=0,025)$ alkotott vélemény. A COVID-19-járvány alatt csökkent a betegelégedettség: a dolgozók viselkedését $(Z=-4,16, p<0,001)$ és a szolgáltatások minőségét $(\mathrm{Z}=-3,88, \mathrm{p}<0,001)$ is rosszabbnak ítélték.

Következtetés: A bevezetésre került intézkedéseink pozitív hatásait mérhetjük a betegelégedettség növekedésén keresztül. Eredményeink rámutatnak arra, hogy a COVID-19-járvány miatti dolgozói megterhelés negatívan befolyásolta a betegelégedettséget.

Orv Hetil. 2020; 161(43): 1819-1823.

Kulcsszavak: betegelégedettség, egykapus ellátórendszer, sürgősségi betegellátó osztály, triázsidő, sürgősségi osztályos diszpécser, kommunikációs tréning, COVID-19

\section{Patient satisfaction during the COVID-19 pandemic in an emergency department}

Introduction and objective: The large number of emergency department (ED) visits increases the workload of caretakers with a decrease in patient satisfaction. We have introduced numerous methods to counteract this in 2019. During the COVID-19 pandemic, patients were admitted to the ED with complaints otherwise dealt with in primary care, additionally $15 \%$ of our staff was delegated to the Coronavirus Centre in April and May, 2020. Our aim was to assess the extent of workload and the effect of the pandemic on patient satisfaction affected by the measures introduced in 2019.

Method: A longitudinal, quantitative, descriptive, questionnaire-based survey and file review was carried out at the University Emergency Department in the University of Pécs, Clinical Centre, involving the period between April 1, 2019 and May 31, $2020(\mathrm{n}=999) .354$ files were analyzed in the first period of the survey, 645 in the second one, along with the use of admission numbers. Data were analyzed by descriptive statistics using independent sample T-test and Mann-Whitney test $(\mathrm{p}<0.05)$.

Results: In the first months of the survey, $51 \%$ of the patients and relatives rated positive the ED of the University of Pécs, while this increased to $99 \%$ by November 2019 . Following the compulsory trainings and institutional restructuring, the opinion improved on nursing staff $(\mathrm{Z}=-2.25, \mathrm{p}=0.024)$, on physicians $(\mathrm{Z}=-2.25, \mathrm{p}=0.024)$ and on 
the department $(\mathrm{Z}=-2.24, \mathrm{p}=0.025)$. During the COVID-19 pandemic, patient satisfaction decreased: the attitude of $\operatorname{staff}(\mathrm{Z}=-4.16, \mathrm{p}<0.001)$ and the quality of service $(\mathrm{Z}=-3.88, \mathrm{p}<0.001)$ was thought to be impaired.

Conclusion: The positive effect of the introduced actions can be measured via patient satisfaction. We have demonstrated that the extra workload had a negative effect on patient satisfaction.

Keywords: patient satisfaction, single-gate entry, emergency department, triage time, ED dispatcher, communication training, COVID-19

Deák A, Fusz K, Kanizsai P. [Patient satisfaction during the COVID-19 pandemic in an emergency department]. Orv Hetil. 2020; 161(43): 1819-1823.

(Beérkezett: 2020. augusztus 17.; elfogadva: 2020. augusztus 31.)

\section{Rövidítések}

COVID-19 = (coronavirus disease 2019) koronavírus-betegség 2019; PTE KK KEK = Pécsi Tudományegyetem, Klinikai Központ, Koronavírus Ellátó Központ; PTE KK SOT SBO = Pécsi Tudományegyetem, Klinikai Központ, Sürgősségi Orvostani Tanszék, Sürgősségi Betegellátó Osztály; SOD = sürgősségi osztályos diszpécser

A hazai egészségügyi ellátás leginkább célkeresztben lévő pontjai közé tartoznak a sürgősségi betegellátó osztályok (SBO-k) [1-5]. Az egykapus rendszer bevezetése óta, amely a betegeket egy ponton lépteti be az egészségügyi ellátórendszerbe, a betegforgalom a legmagasabb progresszivitású ellátóhelyeken [1-3] a duplájára vagy még ennél is magasabb számmal növekedett. A legmagasabb, III. progresszivitási szintü SBO-k [1-5] terhei, betegszámai semmit sem csökkentek azzal, hogy minden városi kórházban létrehoztak kisebb sürgősségi betegellátó egységeket. A „vidéki” SBO-k létrehozásával a III. progresszivitású nagyobb SBO-k betegelégedettségi szempontból is nehezebb helyzetbe kerültek. A kisebb városi kórházak a 4., 5. triázskategóriába tartozó betegek ellátásával a saját betegelégedettségüket javítani tudták, a 3., 2., 1. triázskategóriába kerülő betegeket pedig továbbküldték a magasabb ellátóegységek, a III. progresszivitás felé. Így a nagyobb SBO-k, mint a Pécsi Tudományegyetem, Klinikai Központ, Sürgősségi Orvostani Tanszék, Sürgősségi Betegellátó Osztály (PTE KK SOT SBO) betegeinek összetétele a rosszabb állapotú betegekkel emelkedett. A kritikus állapotú vagy sürgős állapotú betegek számának növekedésével a kevésbé sürgős ellátást igénylő, 4., 5. triázskategóriás betegek ellátási ideje növekszik, így a betegelégedettség rosszabb lesz. A sürgős és kritikus állapotú esetszámok növekedésével a szakdolgozók, orvosok pszichikus és szomatikus megterhelése is növekszik. A dolgozóknak kevesebb sikerélménnyel volt kapcsolatuk, ami megint csak a „burnout” gyorsabb kialakulásához vezethetett volna $[6,7]$. A nagy betegszám mind a betegelégedettséget, mind a dolgozói megterhelést negatív irányba terelte. A páciensek elégedetlenebbek lettek, a dolgozói elvándorlás megnövekedett ezeken a területeken. Az állandó stresszhelyzet nö- velte a szakdolgozók egymás és a betegek közötti konfliktusok számát. Ennek a tendenciának a megállítására és javítására több módszert is bevezettünk 2019ben, kommunikációs tréningeket indítottunk, sürgősségi osztályos diszpécser (SOD-) munkakört [8] vezettünk be, a triázsidóket nagymértékben csökkentettük, valamint a szakorvosok és a szakápolók számát növeltük.

Az EFOP 3.4.3.-16-2016-00005. számú, „Korszerú egyetem a modern városban: Értékközpontúság, nyitottság és befogadó szemlélet egy 21. századi felsőoktatási modellben” címú pályázatának keretében „Kommunikációs tréning a PTE KK Sürgősségi Betegellátó Osztály dolgozói számára" címü tréningen vettek részt a dolgozók kis csoportokban, kétszer 8 órában (2019. május). Témakörök: 1. Kommunikáció nyugtalan, agresszív betegekkel, 2. Kommunikáció hozzátartozókkal, 3. Konfliktuskezelés, 4. Stresszoldás kommunikációs és kognitív módszerekkel, 5. Sajátos kommunikációs helyzetek: kríziskommunikáció, szuggesztív kommunikáció.

Klinikánkon a szakdolgozók flexibilis munkarendben dolgoznak, ami szintén növeli a dolgozók elégedettségét $[9,10]$.

$\mathrm{Az}$ amúgy is nehéz helyzetben lévő SBO-k terhei 2020-ban, az új koronavírus okozta megbetegedés miatti járványhelyzettel még jobban megnövekedtek [11, 12]. Ugyan a járvány miatt az egészségügyi járó- és fekvőbeteg-ellátás elektív beavatkozásai megszű́ntek, a sürgősségi betegellátást ez nem érintette. Sőt a Pécsi Tudományegyetem, Klinikai Központ, Koronavírus Ellátó Központ (PTE KK KEK) létrehozásával az amúgy is emelkedett betegszámmal dolgozó PTE KK SOT SBO átdelegálta szakdolgozóinak több mint 15\%-át. Feltételeztük, hogy a februári hírek hatására a COVID-19-járvánnyal kapcsolatban, majd a márciusban regisztrált magyarországi fertőzöttek és a bevezetett kijárási korlátozás [13] miatt bizonyos panaszokkal kisebb arányban fordulnak a SBO-hoz, mint korábban. A betegszám 2020. áprilisban 10\%-kal kevesebb volt ugyan a 2019. májusihoz képest, ez a csökkenés azonban a következő hónapban már emelkedett betegszámot mutatott az elózó évhez képest. Az egészségügyi ellátórendszer „bezárásával” a betegek a PTE KK SOT SBO-t keresték fel azon pana- 
szaikkal, amelyekkel amúgy a háziorvosukat vagy a szakambulanciákat keresték volna fel.

Kihívást jelentett számunkra a hirtelen bekövetkezett COVID-19-járvány okozta védőfelszerelések folyamatos, mindennapi használatának bevezetése. Ezen védőfelszerelések is csak fokozták a diszkomfortérzetet mind a betegek, mind az ellátószemélyzet körében, mivel a beteg nem látta az orvost/ápolót a védőfelszerelés mögött, és az orvos/ápoló sem a beteget. A szakdolgozók egész napos védőfelszerelésben való szakápolása hatással volt a testi, lelki jólét romlására is [14-16]. A mindennapi munkánk során szerzett és a független - egyes szociális ellátóközpontoktól, gyámügyi ellátóktól és a különböző szeretetszolgálatoktól érkező - visszajelzések alapján erre következtettünk. Ezt mérhetővé is tettük mind kérdőívvel, mind a MedSol egészségügyi medikai rendszer statisztikai fejlesztésével, aminek köszönhetően mérni tudtuk a pontos triázsidőket. Tanszékünk egyik leghangsúlyosabb feladatai közé tartozik a pozitív visszajelzések növelése, a betegelégedettség növelése [17].

\section{Módszer}

\section{Minta}

Longitudinális, kvantitatív, leíró jellegű, kérdőíves felmérést és dokumentumelemzést végeztünk a PTE KK SOT SBO-n 2019. április 1. és 2020. május 31. között ( $\mathrm{n}=$ 999). A felmérés első részében (2019-ben) 354, a második részében (2020-ban) 645 kérdőívet elemeztünk, valamint a dokumentumelemzés során a betegszámokat használtuk fel. A felmérésben részt vevők 72\%-a nő, 62,5\%-a 50 év feletti, 78\%-a városban él, és 98\%-uk nappali múszakban érkezett.

\section{Méröeszköz}

A betegelégedettség felmérése anonim, rövid, saját szerkesztésű, ötpontos Likert-skálákat tartalmazó kérdőíven történt, amelyen a dolgozók viselkedését és a szolgáltatások minőségét értékelték a páciensek és hozzátartozók. A kérdőív az alábbi kérdéscsoportokat tartalmazza: szociodemográfiai adatok (nem, kor, lakhely), tájékoztatás, az ellátás minősége, dolgozói viselkedés, várakozási idő, az ellátás ideje, tisztaság. Továbbá megfogalmazhatták tapasztalataikat megjegyzésként. A dokumentumelemzés során a MedSol-rendszerben található betegforgalom-adatokat és az egyes panaszok esetszámait használtuk fel.

\section{Statisztikai elemzés}

A statisztikai módszereket MS Excel 2007 (Microsoft Corp., Redmond, WA, USA) és SPSS 20.0 (IBM Corp., Armonk, NY, USA) programokkal végeztük: leíró statisztika, kétmintás t-próba, Mann-Whitney-próba, Kruskal-Wallis- és Dunn-teszt. Az eredményeket $\mathrm{p}<0,05$ esetén tekintettük szignifikánsnak.

\section{Eredmények}

\section{Betegelégedettség a COVID-19-járvány elött}

2019-ben a kommunikációs tréningek indítása, a SODmunkakör bevezetése, a triázsidők nagymértékü csökkentése, a szakorvosok és a szakápolók számának növelése hatással volt a betegelégedettségre. 2019 áprilisától nagyobb számban kezdtük el a betegelégedettség felmérését, egyre több kérdőivet töltettünk ki a betegekkel (átlagosan 44 kérdőív/hónap, előtte átlagosan 5 kérdőiv/hónap). A felmérés első hónapjában a páciensek és hozzátartozók 51\%-a értékelte pozitívan a SBO-t, míg novemberre ez az arány 99\%-ra emelkedett.

A kommunikációs tréninget és az egyéb intézkedéseket követóen pozitív irányba változott az ápolókról $(\mathrm{Z}=$ $-2,25, \mathrm{p}=0,024)$, az orvosokról $(\mathrm{Z}=-2,25, \mathrm{p}=0,024)$ és az osztályról $(\mathrm{Z}=-2,24, \mathrm{p}=0,025)$ alkotott vélemény (1. táblázat).

\section{Betegelégedettség a COVID-19-járvány alatt}

A vizsgálat második részében a 2020. január 1. és május 31. között kitöltött kérdőíveket elemeztük ( $\mathrm{n}=645)$, ekkor már havonta átlagosan 129 kérdőívet töltöttek ki a páciensek és hozzátartozók. A kérdőív több szempont szerint értékelte a SBO-t, mint a 2019-ben használt, több Likert-skálát (1-5 pont) alkalmaztunk. Januártól

1. táblázat | Pozitív változások a 2019-ben bevezetett intézkedések hatására $(\mathrm{n}=354)$

\begin{tabular}{|c|c|c|c|c|c|c|c|c|c|c|}
\hline \multirow{2}{*}{$\begin{array}{l}\text { Értékelt } \\
\text { dolgozók }\end{array}$} & \multicolumn{4}{|c|}{ Intézkedések előtt } & \multicolumn{4}{|c|}{ Intézkedések után } & \multicolumn{2}{|c|}{ Mann-Whitney-teszt } \\
\hline & Átlag & $\begin{array}{c}\text { Alsó } \\
\text { kvartilis }\end{array}$ & Medián & $\begin{array}{c}\text { Felső } \\
\text { kvartilis }\end{array}$ & Átlag & $\begin{array}{c}\text { Alsó } \\
\text { kvartilis }\end{array}$ & Medián & $\begin{array}{c}\text { Felső } \\
\text { kvartilis }\end{array}$ & $\mathrm{Z}$ & $\mathrm{p}$ \\
\hline Ápolók & $3,46 \pm 0,12$ & 3,33 & 3,48 & 3,59 & $4,86 \pm 0,16$ & 4,70 & 4,92 & 5,00 & $-2,25$ & $\mathrm{p}=0,024$ \\
\hline Orvosok & $3,52 \pm 0,21$ & 3,33 & 3,48 & 3,64 & $4,78 \pm 0,26$ & 4,78 & 4,56 & 5,00 & $-2,25$ & $\mathrm{p}=0,024$ \\
\hline $\begin{array}{l}\text { Az egész } \\
\text { osztály }\end{array}$ & $2,76 \pm 0,14$ & 2,52 & 2,83 & 2,86 & $4,61 \pm 0,23$ & 4,42 & 4,56 & 4,82 & $-2,24$ & $\mathrm{p}=0,025$ \\
\hline
\end{tabular}


2. táblázat |A dolgozók viselkedésének és a szolgáltatások minőségének értékelése 2020. január l. és május 31 . között (n=645)

\begin{tabular}{|c|c|c|c|c|c|c|c|c|c|c|}
\hline \multirow[t]{2}{*}{ Értékelési szempont } & \multicolumn{4}{|c|}{ 2020. január 1.-március 31.} & \multicolumn{4}{|c|}{ 2020. április 1.-május 31.} & \multicolumn{2}{|c|}{ Mann-Whitney-teszt } \\
\hline & Átlag & $\begin{array}{c}\text { Alsó } \\
\text { kvartilis }\end{array}$ & Medián & $\begin{array}{c}\text { Felső } \\
\text { kvartilis }\end{array}$ & Átlag & $\begin{array}{c}\text { Alsó } \\
\text { kvartilis }\end{array}$ & Medián & $\begin{array}{c}\text { Felső } \\
\text { kvartilis }\end{array}$ & $\mathrm{Z}$ & $\mathrm{p}$ \\
\hline A dolgozók viselkedése & $4,64 \pm 0,12$ & 4,56 & 4,67 & 4,72 & $4,52 \pm 0,09$ & 4,41 & 4,55 & 4,59 & $-4,16$ & $<0,001$ \\
\hline $\begin{array}{l}\text { A szolgáltatások } \\
\text { minősége }\end{array}$ & $4,59 \pm 0,12$ & 4,51 & 5,61 & 4,67 & $4,47 \pm 0,08$ & 4,41 & 4,46 & 4,54 & $-3,88$ & $<0,001$ \\
\hline
\end{tabular}

márciusig a „COVID-19-járvány előtti” kategóriába kerültek a betegelégedettségi adatok $(\mathrm{n}=456)$, míg az áprilisi és májusi kérdőívek eredményei a „COVID-19-járvány alatti” csoportba $(\mathrm{n}=189)$. Az elégedett betegek aránya január és március között 94\%, míg áprilisban és májusban $83 \%$ volt.

A dolgozók viselkedését a páciensek rosszabbnak ítélték meg 2020. április 1. és május 31. között, azaz a COVID-19-járvány időszakában, mint előtte $(\mathrm{Z}=$ $-4,16, p<0,001$ ). A szolgáltatások (orvosi és ápolói ellátás, adminisztráció, tájékoztatás, tisztaság) minőségét rosszabbnak ítélték áprilisban és májusban, mint előtte $(\mathrm{Z}=-3,88, \mathrm{p}<0,001)$ (2. táblázat).

A nem és a lakhely nincs összefüggésben a betegelégedettség mértékével ( $\mathrm{p}>0,05)$. A korcsoportok között volt különbség, ugyanis az 50 évnél idősebb páciensek és hozzátartozók betegelégedettsége alacsonyabb. Kruskal-Wallis- és Dunn-teszttel igazoltuk, hogy alacsonyabbra értékelték a többi korcsoportnál (18-30 év, 31-50 év) az orvosok viselkedését ( $\mathrm{p}<0,001)$, az ápolók viselkedését $(\mathrm{p}<0,001)$, a diszpécser viselkedését $(\mathrm{p}<0,001)$, a betegkísérő viselkedését $(\mathrm{p}<0,001)$, az orvosi ellátást $(\mathrm{p}<0,001)$, az ápolói ellátást $(\mathrm{p}<0,001)$, a tájékoztatást $(p<0,001)$ és a mellékhelyiségek tisztaságát $(\mathrm{p}<0,001)$.

\section{A COVID-19-járvány hatása a betegszámra}

Feltételeztük, hogy a februári hírek hatására a COVID19-járvánnyal kapcsolatban, majd a márciusban regisztrált magyarországi fertőzöttek és a bevezetett kijárási korlátozás miatt bizonyos panaszokkal kisebb arányban fordulnak a SBO-hoz, mint korábban. Volumenhiány $(\mathrm{t}=3,0, \mathrm{p}=0,04)$, alkoholabúzus és etanolmérgezés $(\mathrm{t}=3,78, \mathrm{p}=0,02)$, valamint hypertoniás krízis $(\mathrm{t}=3,3$, $\mathrm{p}=0,03)$ miatt kevesebben érkeztek az osztályra 2020 . február 1. és április 30. között, mint 2019-ben ugyanebben az időszakban. A törések, zúzódások és sebek miatti betegszámcsökkenés tendenciaszintü volt $(\mathrm{t}=2,6, \mathrm{p}=$ $0,06)$.

A betegforgalom 2020. áprilisban 10\%-kal kevesebb volt, mint 2019. áprilisban; a többi hónap esetén nem figyeltünk meg csökkenést, a szakdolgozók száma viszont 15\%-kal kevesebb volt áprilisban és májusban a PTE KK KEK-be való áthelyezésük miatt.

\section{Megbeszélés}

A bevezetésre került intézkedéseink hatásait mérhetjük a betegelégedettség növekedésén keresztül. Az a feltételezésünk, hogy a betegelégedettség növelésében nagy szerepe van a dolgozói elégedettségnek, beigazolódott. Közvetlenül a COVID-19-járvány előtt és után is a betegelégedettség jóval nagyobb volt, mint mielőtt kommunikációs tréningeket indítottunk, SOD-munkakört vezettünk be, a triázsidőket nagymértékben csökkentettük, a szakorvosok és szakápolók számát növeltük. A járvány ideje alatt ez az elégedettség csökkent ugyan, de még így is az elégedett betegek aránya ezekben a hónapokban $83 \%$, valamint a dolgozók viselkedése és a szolgáltatások minősége is jó értékelést kapott. A járvány ideje alatt a dolgozói megterhelés növekedett, ezáltal elégedettségük csökkent, és ennek hatása a betegelégedettség csökkenésében is megnyilvánult. A szociodemográfiai adatok közül az életkor függött össze a betegelégedettséggel, ugyanis az 50 évnél idősebb korosztály rosszabbnak értékelte a dolgozók viselkedését és a szolgáltatások minőségét is.

A kérdőív rövid, a betegelégedettség egyes faktorait vizsgálja, mégis alkalmas arra, hogy gyors visszajelzést kapjunk munkánkról.

Kutatásunk korlátja a vizsgálat nem önkontrollos jellege, valamint a kérdőívkitöltési hajlandóság egyéni különbözősége és az ebből eredő szelekciós torzítás, továbbá hogy a minta nem reprezentatív.

\section{Következtetés}

Eredményeinkből következtethetünk arra, hogy a dolgozók elégedettsége és megfelelő kommunikációja hatással van a betegelégedettségre, emiatt a 2019-ben bevezetett intézkedéseket folytatva mind a betegelégedettséget, mind pedig a dolgozói elégedettséget fenn tudjuk tartani, sőt további új intézkedésekkel még tovább tudjuk növelni. Hasonló következtetésekre jutottak Tóth és mtsai 2004-ben [18]. A kommunikációs tréningeket bővítve konfliktuskezeléssel javítani tudjuk a jövőben is az elégedettséget [19]. Eredményeink felhívják a figyelmet arra is, hogy az idősebb páciensek még több odafigyelést igényelnek.

Hosszú távon a PTE KK SOT SBO-t szeretnénk teljesen digitalizálni a betegek felvételétől egészen a betegek 
elbocsátásáig, a betegelégedettségi kérdőív digitális, akár otthonról kitölthető alkalmazásával bezárólag. Törekvéseink és céljaink nem túlzottan elrugaszkodott célok, hiszen jelenleg is ezeket a célokat próbálja minden szakmai terület minél jobban kihasználni. A dolgozók bevonása a digitalizációs intézkedésekbe javítja a szakdolgozók közötti kapcsolatot, így az elégedettséget is, és a végtermék olyan eszköz lesz, mely mindenki számára elfogadásra kerül. Ehhez hasonlóan a mesterséges intelligenciának a betegek ellátásába való bevonása javítja az ellátás minőségét, kizárja a hibalehetőségeket, és lehetőséget ad a nagyobb és pontosabb betegtájékoztatásra [20]. Összefoglalva, már az eddig történt intézkedések is javítottak a beteg- és dolgozói elégedettségen. Ha a hosszú távú terveket is meg tudjuk valósítani, akkor ezt az elégedettségi szintet tartóssá tudjuk tenni.

\section{Az etikai engedély száma: PTE/2743-1/2020; KK/94-} $1 / 2020$.

Anyagi támogatás: A közlemény megírása, illetve a kapcsolódó kutatómunka anyagi támogatásban nem részesült.

Szerzôi munkamegosztás: D. A.: A célkitüzések megfogalmazása, szakirodalmi áttekintés, adatbázis készítése, a kézirat megszövegezése. F. K.: Statisztikai elemzés, a kézirat megszövegezése. K. P.: A célkitűzések megfogalmazása, a kézirat megszövegezése. A cikk végleges változatát valamennyi szerző elolvasta és jóváhagyta.

Érdekeltségek: A szerzőknek nincsenek érdekeltségeik.

\section{Irodalom}

[1] Betlehem J. (ed.) First course of action in an emergency - first aid. [Első teendő́k sürgős esetekben - elsősegélynyújtás.] Medicina Könyvkiadó, Budapest, 2012. [Hungarian]

[2] Kövi R. The development of progressivity as a professional tool for structure formation. [A progresszivitás kialakítása, mint a struktúra formálás szakmai eszköze.] IME 2010; 9: 17-23. [Hungarian]

[3] Roberts JR. Roberts \& Hedges' clinical procedures in emergency medicine. Elsevier Saunders, Philadelphia, PA, 2014.

[4] Arnold JL. International emergency medicine and the recent development of emergency medicine worldwide. Ann Emerg Med. 1999; 33: 97-103.

[5] Gőbl G. (ed.) Oxiology. [Oxiológia.] Medicina Könyvkiadó, Budapest, 2006. [Hungarian]

[6] Arora M, Asha S, Chinnappa J, et al. Review article: burnout in emergency medicine physicians. Emerg Med Australas. 2013; 25: $491-495$.
[7] Santarone K, McKenney M, Elkbuli A. Preserving mental health and resilience in frontline healthcare workers during COVID-19. Am J Emerg Med. 2020; 38: 1530-1531.

[8] 44/2018. (XII. 19.) EMMI Decree, amending the ministerial decrees concerning emergency care. [44/2018. (XII. 19.) EMMI rendelet egyes, a sürgősségi ellátást érintő miniszteri rendeletek módosításáról.] Available from: https://www.hbcs.hu/ uploads/jogszabaly/2807/fajlok/44_2018_XII\%2019_\%20 EMMI\%20rendelet\%20_feld.pdf [accessed: August 13, 2020]. [Hungarian]

[9] Fusz K, Pakai A, Kívés Z, et al. Work schedules in the Hungarian health care system and the sleep quality of nurses. [Munkarendek a hazai egészségügyi rendszerben, és az ápolók alvásminősége.] Orv Hetil. 2016; 157: 379-384. [Hungarian]

[10] Fusz K, Tóth Á, Fullér N, et al. Sleep quality of nurses working in shifts - Hungarian adaptation of the Bergen Shift Work Sleep Questionnaire. [Váltott mûszakban dolgozó ápolók alvásminőségének vizsgálata a magyar nyelvre adaptált Bergen Shift Work Sleep Questionnaire alkalmazásával.] Orv Hetil. 2015; 156: 2003-2008. [Hungarian]

[11] Chavez S, Long B, Koyfman A, et al. Coronavirus Disease (COVID-19): A primer for emergency physicians. Am J Emerg Med. 2020 Mar 24. doi: 10.1019/j.ajem.2020.03.036. [Online ahead of print].

[12] Spina S, Marrazzo F, Migliari M, et al. The response of Milan's Emergency Medical System to the COVID-19 outbreak in Italy. Lancet 2020; 395: e49-e50.

[13] The Government of Hungary. Information site on coronavirus. [Magyarország Kormánya. Tájékoztató oldal a koronavírusról.] Available from: https://koronavirus.gov.hu/\#/ [accessed: August 13, 2020]. [Hungarian]

[14] Adams JG, Walls RM. Supporting the health care workforce during the COVID-19 global epidemic. JAMA 2020; 323: 14391440 .

[15] Smereka J, Szarpak L. The use of personal protective equipment in the COVID-19 pandemic era. Am J Emerg Med. 2020; 38: $1529-1530$.

[16] Turer RW, Jones I, Rosenbloom ST, at al. Electronic personal protective equipment: a strategy to protect emergency department providers in the age of COVID-19. J Am Med Inform Assoc. 2020; 27: 967-971.

[17] Taylor C, Benger JR. Patient satisfaction in emergency medicine. Emerg Med J. 2004; 21: 528-532.

[18] Tóth KJ, Berényi T, Mezőfi M. Patient satisfaction survey to improve emergency care. [Betegelégedettségi vizsgálat a sürgősségi ellátás fejlesztése céljából.] Orv Hetil. 2004; 145: 625-629. [Hungarian]

[19] Molnár R, Sági Z, Fejes Zs, et al, Possibilities of doctor-patient communication. Understanding patients' expectations. [Az orvos-beteg kommunikáció új lehetőségei a betegek elvárásai alapján.] Orv Hetil. 2018; 159: 2136-2143. [Hungarian]

[20] Varga Zs, Horváth T. Patients' preferences for health-related use of Internet. [Betegpreferenciák az egészségügyi célú internethasználatban.] Orv Hetil. 2018; 159: 2175-2182. [Hungarian]

(Deák András, Pécs, Ifjúság útja 13., 7624 e-mail: deak.andras@pte.hu)

A cikk a Creative Commons Attribution 4.0 International License (https://creativecommons.org/licenses/by/4.0/) feltételei szerint publikált Open Access közlemény, melynek szellemében a cikk bármilyen médiumban szabadon felhasználható, megosztható és újraközölhető, feltéve, hogy az eredeti szerző és a közlés helye, illetve a CC License linkje és az esetlegesen végrehajtott módosítások feltüntetésre kerülnek. (SID_1) 